\title{
Relationships between soil properties, topography and land use in the Van Lake Basin, Turkey
}

\author{
Siyami Karaca a,*, Füsun Gülser a, Ramazan Selçuk b \\ a Van Yüzüncü Yll University, Faculty of Agriculture, Department of Soil Science and Plant Nutrition, Van, Turkey \\ b GAP International Agricultural Reseach and Training Center, Diyarbakır, Turkey
}

\section{Article Info}

Received : 21.06.2017

Accepted : 20.10 .2017

\begin{abstract}
The objective of this study was to determine the relationship between soil properties and different topography and land uses in the Van Lake Basin, Turkey. It has sharp and sheer slopes, and the big differences on altitude generally occur from the mountainous formations. Surface soil samples $(0-20 \mathrm{~cm})$ were taken from 40 different points with three different topography (backslope, footslope and terrace) and three different landuses (wheat, clover and pasture). Some of the studied soil properties (soil texture, electrical conductivity [EC], $\mathrm{pH}$, lime content, organic matter content, macro and micro nutrients) changed in response to land use and topography. The clay, boron content, $\mathrm{pH}$ and EC values increased from the backslope to the terrace. Soil organic matter and EC values were lower in cultivated wheat and clover fields than in uncultivated pasture. The EC values had significant positive correlations with $\mathrm{CaCO}_{3}$, organic matter, $\mathrm{K}, \mathrm{B}, \mathrm{Cu}$ contents at $5 \%$ level and with $\mathrm{Mg}$ at $1 \%$ level statistically. The soil nutrient contents of cultivated wheat and clover fields were generally lower than the uncultivated pasture. The nutrient contents of soils in cultivated fields decreased due to nutrient uptake by crops. Soil texture, EC, pH, lime, organic matter and nutrient contents significantly varied in different topographic positions due to leaching, transporting and accumulation.
\end{abstract}

Keywords: Land use, nutrient, soil properties, topography.

(C) 2018 Federation of Eurasian Soil Science Societies. All rights reserved

\section{Introduction}

Parent material, climate and geological history strongly affect soil properties at the regional and continental scale. However, both topography and land use can influence the soil physical and chemical properties. The availability of the essential elements of soil for plant growth can change depending on the land use and topography. These factors also affect water infiltration and degree of evapotranspiration by modifying the soil moisture content and consequently influencing the yield, plant litter production and decomposition (Birkeland, 1999).

Topography influence drainage, runoff, soil temperature, soil erosion and soil formation (Aandahl, 1948). Differences in soil formation along a hillslope result from the differences in soil properties (Brubaker et al.,1993). Ovalles and Collins (1986) reported that soil physical properties such as clay content distribution with depth, sand content and $\mathrm{pH}$ were highly correlated with landscape position. Several researchers (Miller et al., 1988; Bhatti et al., 1991) reported that organic matter content varies by slope position. In contrast, organic carbon content, clay content, and surface thickness increases from the backslope to the footslope (Young and Hammer, 2000; Garten and Ashwood, 2002; Yoo et al., 2006).

\footnotetext{
${ }^{*}$ Corresponding author.

Van Yüzüncü Yıl University, Faculty of Agriculture, Department of Soil Science and Plant Nutrition, 65080 Van, Turkey Tel.: +904322251104 E-mail address: s.karaca@yyu.edu.tr e-ISSN: 2147-4249 DOI: 10.18393 /ejss.348412
} 
Land use practices also influence the soil properties. Barreto et al. (2000) reported that three types of land use (forest, abandoned pasture and active pasture) had significant effects on the soil physical and chemical

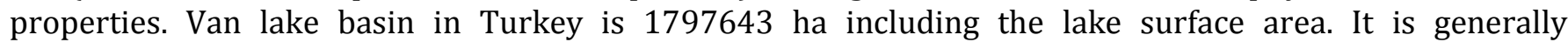
mountainous and has sharp and sheer slopes. The mean altitude of the basin is around $1600-2500 \mathrm{~m}$. Water erosion and soil loss are common in the basin. The natural vegetation is meadow and the climate is continental climate in the region. The objective of the current study was to determine the effects of different topography and land use on soil physical and chemical properties in the basin.

\section{Material and Methods}

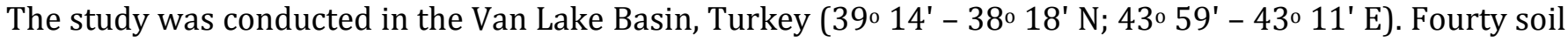
samples were collected from 0-20 cm soil depth. Each soil sample was separately air-dried, ground and passed through a 2-mm sieve prior to determining the chemical and physical properties. Some soil physical and chemical properties of soil were determined as follows; texture by Bouyoucos hydrometer method (Black, 1965), organic matter by modified Walkley-Black method, available phosphorus by Olsen method, $\mathrm{pH}$ in 1:1 soil: water suspension by $\mathrm{pH}$ meter, salt content in the same suspension by EC meter, lime content by Scheiblercalcimeter, potasium, calcium and magnesium by the extraction with $1 \mathrm{~N}$ neutral ammonium acetate, micro nutrients by the extraction with DTPA extraction solution by using atomic absorption spectrophotometers (Thermo ICE 3000 Series) according to Kacar (1994).

Variance analyses of the experimental data were done using SPSS statistic program and significantly different means were shown with LSD test. Significant levels of data among the soil properties were shown with * at $\mathrm{P}<0.05$ and ${ }^{* *}$ at $\mathrm{P}<0.01$ (Steel and Tore, 1996).

\section{Results}

Changes in clay, $\mathrm{pH}, \mathrm{EC}$, lime, organic matter, exchangeable cations and micronutrient contents according to the different topography are given in Table 1 . The clay content $(\mathrm{P}<0.05)$, boron content and $\mathrm{pH}$ value $(\mathrm{P}<$ 0.05 ) were significantly influenced by the different topography. These parameters increased from the backslope to the terrace. The clay content means were $17.00 \%, 20.36 \%$ and $25.76 \%$ in the backslope, footslope and terrace, respectively (Figure1).

Table 1 . The effects of different physiographic units on soil properties in the Van Lake basin

\begin{tabular}{|c|c|c|c|c|c|c|c|c|c|c|c|}
\hline & Phy. † & Min. & Max. & Mean & St. Dv. & & Phy. † & Min. & Max. & Mean & St. Dv. \\
\hline & 1 & 4.00 & 38.00 & $17.00 \mathrm{a}^{*}$ & 11.62 & & 1 & 0.08 & 0.93 & 0.52 & 0.28 \\
\hline \multirow[t]{3}{*}{ Clay, \% } & 2 & 12.00 & 28.00 & $20.36 \mathrm{a}$ & 5.39 & Exc. Ca, \% & 2 & 0.29 & 1.00 & 0.66 & 0.25 \\
\hline & 3 & 10.00 & 40.00 & $25.76 \mathrm{~b}$ & 8.85 & & 3 & 0.19 & 0.81 & 0.62 & 0.16 \\
\hline & 1 & 18.00 & 58.00 & 34.42 & 12.16 & & 1 & 0.02 & 0.07 & 0.04 & $\overline{0.02}$ \\
\hline \multirow[t]{3}{*}{ Silt, \% } & 2 & 24.00 & 56.00 & 33.55 & 10.79 & Exc. Mg,\% & 2 & 0.02 & 0.05 & 0.04 & 0.01 \\
\hline & 3 & 10.00 & 46.00 & 30.53 & 8.25 & & 3 & 0.02 & 0.10 & 0.05 & 0.02 \\
\hline & 1 & 28.00 & 72.00 & 48.58 & 13.27 & & 1 & 0.02 & 0.17 & 0.06 & $\overline{0.04}$ \\
\hline \multirow[t]{3}{*}{ Sand, \% } & 2 & 24.00 & 64.00 & 46.09 & 10.79 & Exc. K,\% & 2 & 0.02 & 0.10 & 0.05 & 0.02 \\
\hline & 3 & 25.00 & 76.00 & 43.71 & 15.09 & & 3 & 0.03 & 0.13 & 0.05 & 0.02 \\
\hline & 1 & 6.57 & 8.24 & $7.68 b^{*}$ & 0.61 & & 1 & 0.18 & 1.23 & $0.51 a^{*}$ & 0.32 \\
\hline \multirow[t]{3}{*}{$\mathrm{pH}$} & 2 & 6.17 & 8.30 & $7.89 \mathrm{ab}$ & 0.61 & $\mathrm{~B}, \mathrm{mg} \mathrm{kg}^{-1}$ & 2 & 0.16 & 1.14 & $0.64 \mathrm{ab}$ & 0.32 \\
\hline & 3 & 6.87 & 9.13 & $8.15 \mathrm{a}$ & 0.49 & & 3 & 0.21 & 2.47 & $0.90 \mathrm{a}$ & 0.63 \\
\hline & 1 & 84.50 & 574.50 & 251.76 & 136.73 & & 1 & 0.48 & 2.25 & 1.31 & 0.66 \\
\hline \multirow[t]{3}{*}{$\mathrm{EC}, \mu \mathrm{S} \mathrm{cm}^{-1}$} & 2 & 126.80 & 488.00 & 263.24 & 108.24 & $\mathrm{Cu}, \mathrm{mg} \mathrm{kg}^{-1}$ & 2 & 0.44 & 2.50 & 1.17 & 0.70 \\
\hline & 3 & 134.55 & 518.50 & 276.97 & 101.09 & & 3 & 0.37 & 3.25 & 1.25 & 0.78 \\
\hline & 1 & 0.72 & 6.17 & 2.33 & 1.89 & & 1 & 1.98 & 157.10 & 25.21 & 44.09 \\
\hline \multirow[t]{3}{*}{ OM, \% } & 2 & 0.50 & 3.08 & 1.55 & 0.79 & $\mathrm{Fe}, \mathrm{mg} \mathrm{kg}^{-1}$ & 2 & 2.02 & 230.40 & 27.17 & 67.57 \\
\hline & 3 & 0.58 & 5.65 & 2.01 & 1.34 & & 3 & 0.98 & 29.06 & 9.05 & 6.97 \\
\hline & 1 & 1.42 & 44.39 & 14.63 & 17.49 & & 1 & 4.00 & 66.49 & 16.58 & 17.43 \\
\hline \multirow[t]{5}{*}{$\mathrm{CaCO}_{3}, \%$} & 2 & 1.01 & 49.45 & 12.20 & 13.60 & Mn,mg kg-1 & 2 & 6.33 & 39.00 & 11.85 & 9.33 \\
\hline & 3 & 1.62 & 58.37 & 21.28 & 16.51 & & 3 & 1.05 & 31.03 & 9.63 & 6.93 \\
\hline & & & & & & & 1 & 0.30 & 9.70 & 2.55 & 3.30 \\
\hline & & & & & & Zn,mg kg-1 & 2 & 0.39 & 5.73 & 1.11 & 1.54 \\
\hline & & & & & & & 3 & 0.41 & 5.56 & 1.16 & 1.39 \\
\hline
\end{tabular}

†Physiographic units: 1-Backslope, 2-Footslope, 3-Terrace

*significant at 0.05 level. 
It was shown in Figure 2 the pH value was significantly $(\mathrm{P}<0.05)$ lower in the backslope $(7.68)$ than in the terrace (8.15). Soil pH showed a significant positive correlations with $\mathrm{CaCO}_{3}\left(0.391^{*}\right)$, $\mathrm{Ca}\left(0.381^{*}\right), \mathrm{B}$ $\left(0.479^{* *}\right)$, and negative correlations with organic matter $\left(-0.363^{*}\right), \mathrm{Fe}\left(-0.725^{* *}\right), \mathrm{Mn}\left(-0.808^{* *}\right)$ and $\mathrm{Zn}$ $\left(-0.550^{* *}\right)$ contents.

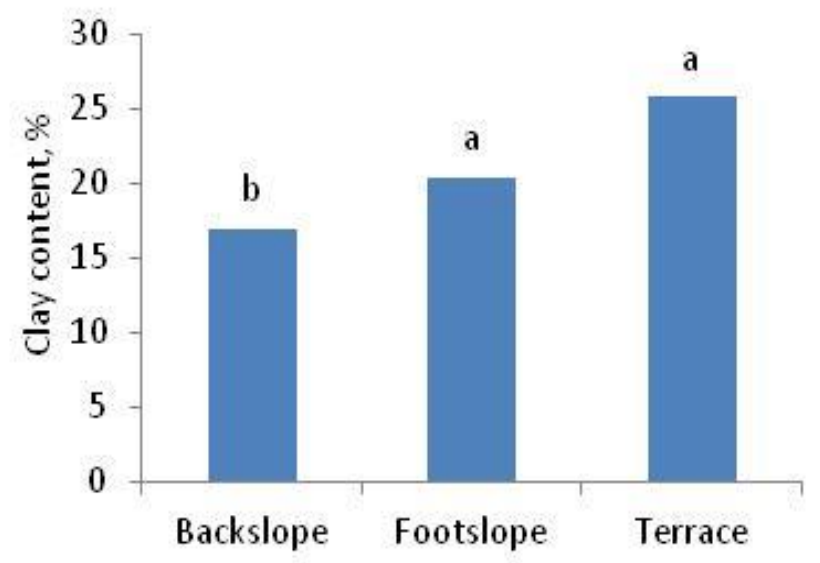

Figure 1. Effect of physiographic units on clay content $(\mathrm{P}<0.05)$

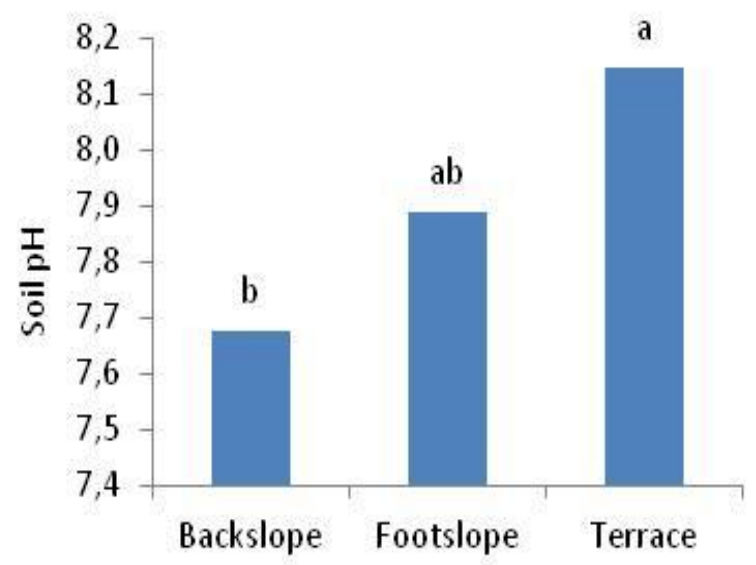

Figure 2. Effect of physiographic units on soil $\mathrm{pH}(\mathrm{P}<0.10)$

The EC values increased from the backslope to the terrace; however, these increments were not found to be significant. The EC values were 251.7, 263.2 and $279.9 \mu \mathrm{S} \mathrm{cm}-1$ in the backslope, footslope and terrace positions, respectively. EC values showed significant positive correlations with $\mathrm{CaCO}_{3}\left(0.361^{*}\right)$, organic matter $\left(0.598^{* *}\right), \mathrm{K}\left(0.620^{* *}\right), \mathrm{Mg}\left(0.420^{* *}\right), \mathrm{B}\left(0.375^{*}\right)$ and $\mathrm{Cu}\left(0.321^{*}\right)$ contents.

There were no significant differences in soil nutrient contents, except boron, among the topographic units in this study. Boron content was significantly $(\mathrm{P}<0.05)$ higher in the terrace position than in the footslope. The boron contents were determined as $0.507 \mathrm{mg} \mathrm{kg}^{-1}, 0.644 \mathrm{mg} \mathrm{kg}^{-1}$ and $0.899 \mathrm{mg} \mathrm{kg}^{-1}$ in backslope, footslope and terrace, respectively (Figure 3).

The mean values of clay content and EC values increased from the shoulder to the terrace position (Figure 4). It was thought that these increments occurred by leaching and moving soil particles throughout slope. Also, lime content and $\mathrm{pH}$ values in terrace position were higher than that in shoulder position. Iron, manganese and zinc contents in surface soil samples decreased from the shoulder to the terrace position due to nutrient uptake by crops in cultivated fields located at terrace positions. The high soil $\mathrm{pH}$, clay, and $\mathrm{CaCO}_{3}$ contents in terrace positions might cause these decreases in micronutrient contents (Table 1).

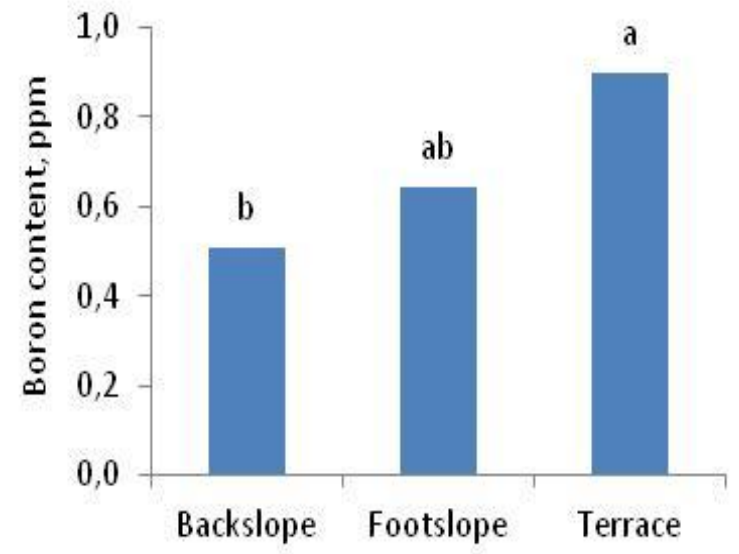

Figure 3. Effect of physiographic units on boron content $(\mathrm{P}<0.10)$

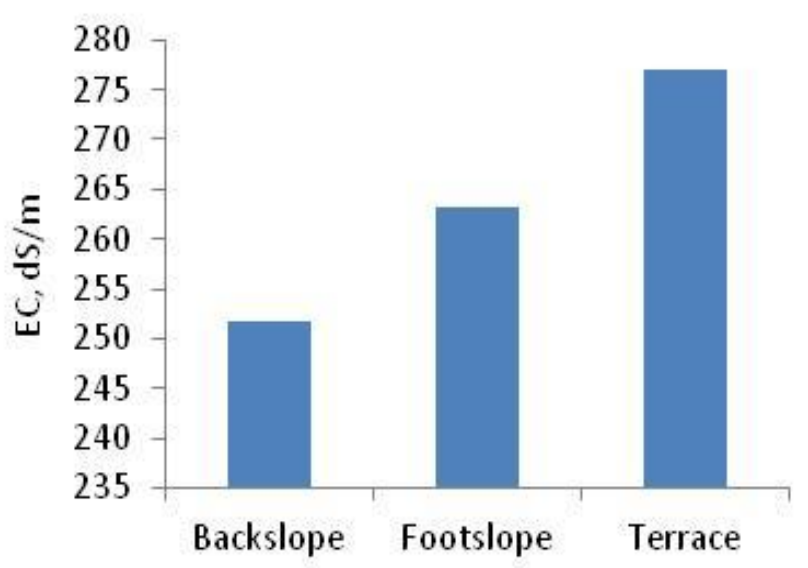

Figure 4. Effect of physiographic units on EC

Changes in clay, $\mathrm{pH}, \mathrm{EC}$, lime, organic matter, exchangeable cations and micronutrient contents according to the different land use are given in Table 2. There were significant effects of land use on soil organic matter (P 
$<0.05), \mathrm{Mg}$ content $(\mathrm{P}<0.01)$, and $\mathrm{EC}(\mathrm{P}<0.05)$. The mean soil organic matter was $1.32 \%, 1.7 \%$ and $2.47 \%$ in cultivated wheat, clover fields and pasture, respectively (Table 2). There was a significant difference in soil organic matter content between wheat fields and pasture. Soil organic matter decreased in cultivated wheat and clover fields relative to the uncultivated pasture (Figure 5). The organic matter content had significant positive correlations with $\mathrm{K}\left(0.547^{* *}\right), \mathrm{Mg}\left(0.374^{*}\right), \mathrm{Cu}\left(0.542^{* *}\right), \mathrm{Fe}\left(0.417^{* *}\right), \mathrm{Mn}\left(0.537^{* *}\right)$ and Zn $\left(0.538^{* *}\right)$ contents.

Table 2. The effects of different land use on soil properties in the Van Lake basin

\begin{tabular}{|c|c|c|c|c|c|c|c|c|c|c|c|}
\hline & L use $†$ & Min. & Max. & Mean & St. Dv. & & L use $\dagger$ & Min. & Max. & Mean & St. Dv. \\
\hline \multirow{3}{*}{ Clay, \% } & 1 & 10.00 & 32.00 & 20.29 & 6.88 & \multirow{3}{*}{ Exch. Ca,\% } & 1 & 0.08 & 1.00 & 0.57 & 0.28 \\
\hline & 2 & 10.00 & 40.00 & 23.50 & 9.45 & & 2 & 0.19 & 0.95 & 0.62 & 0.24 \\
\hline & 3 & 6.00 & 40.00 & 22.43 & 11.63 & & 3 & 0.30 & 0.81 & 0.59 & 0.17 \\
\hline \multirow{3}{*}{ Silt, \% } & 1 & 20.00 & 56.00 & 34.07 & 9.43 & \multirow{3}{*}{ Exch. Mg,\% } & 1 & 0.02 & 0.06 & 0.03 & $\overline{0.01}$ \\
\hline & 2 & 18.00 & 52.00 & 34.00 & 9.63 & & 2 & 0.02 & 0.10 & 0.05 & 0.02 \\
\hline & 3 & 10.00 & 54.00 & 31.21 & 10.64 & & 3 & 0.02 & 0.07 & 0.04 & 0.01 \\
\hline \multirow{3}{*}{ Sand, \% } & 1 & 24.00 & 64.00 & 45.64 & 11.71 & \multirow{3}{*}{ Exch. K,\% } & 1 & 0.02 & 0.10 & 0.05 & $\overline{0.02}$ \\
\hline & 2 & 25.00 & 72.00 & 42.50 & 14.17 & & 2 & 0.03 & 0.07 & 0.05 & 0.01 \\
\hline & 3 & 26.00 & 76.00 & 46.36 & 15.56 & & 3 & 0.02 & 0.17 & 0.06 & 0.04 \\
\hline \multirow{3}{*}{$\mathrm{pH}$} & 1 & 6.60 & 8.35 & 7.89 & 0.49 & \multirow{3}{*}{$\mathrm{B}, \mathrm{mg} \mathrm{kg}^{-1}$} & 1 & 0.22 & 1.14 & 0.58 & 0.35 \\
\hline & 2 & 6.87 & 8.33 & 7.98 & 0.42 & & 2 & 0.21 & 1.07 & 0.64 & 0.23 \\
\hline & 3 & 6.17 & 9.13 & 7.95 & 0.80 & & 3 & 0.16 & 2.47 & 0.85 & 0.72 \\
\hline \multirow{3}{*}{$\mathrm{EC}, \mu \mathrm{S} \mathrm{cm}-1$} & 1 & 84.50 & 355.00 & $219.9 b^{*}$ & 79.19 & \multirow{3}{*}{$\mathrm{Cu}, \mathrm{mg} \mathrm{kg}^{-1}$} & 1 & 0.37 & 2.20 & 0.96 & 0.59 \\
\hline & 2 & 134.55 & 488.00 & $256.2 \mathrm{ab}$ & 93.94 & & 2 & 0.44 & 3.25 & 1.25 & 0.90 \\
\hline & 3 & 139.55 & 574.50 & $303.7 \mathrm{a}$ & 135.41 & & 3 & 0.65 & 2.50 & 1.46 & 0.62 \\
\hline \multirow{3}{*}{$\mathrm{OM}, \%$} & 1 & 0.50 & 4.73 & $1.32 b^{*}$ & 1.12 & \multirow{3}{*}{$\mathrm{Fe}, \mathrm{mg} \mathrm{kg}^{-1}$} & 1 & 0.98 & 53.02 & 8.32 & 13.14 \\
\hline & 2 & 0.94 & 2.35 & $1.71 \mathrm{ab}$ & 0.45 & & 2 & 4.64 & 29.06 & 11.05 & 7.92 \\
\hline & 3 & 0.99 & 6.17 & $2.47 \mathrm{a}$ & 1.58 & & 3 & 3.74 & 230.40 & 36.23 & 68.70 \\
\hline \multirow{6}{*}{$\mathrm{CaCO}_{3}, \%$} & 1 & 1.01 & 39.72 & 13.38 & 12.77 & \multirow{3}{*}{$\mathrm{Mn}, \mathrm{mg} \mathrm{kg}^{-1}$} & 1 & 2.60 & 29.18 & 9.13 & 6.77 \\
\hline & 2 & 1.42 & 58.37 & 16.25 & 20.98 & & 2 & 9.07 & 31.03 & 13.42 & 6.65 \\
\hline & 3 & 1.82 & 39.97 & 16.77 & 13.96 & & 3 & 1.05 & 66.49 & 14.72 & 17.53 \\
\hline & & & & & & \multirow{3}{*}{$\mathrm{Zn}, \mathrm{mg} \mathrm{kg}^{-1}$} & 1 & 0.30 & 4.02 & 0.92 & 1.07 \\
\hline & & & & & & & 2 & 0.52 & 3.31 & 0.92 & 0.85 \\
\hline & & & & & & & 3 & 0.42 & 9.70 & 2.18 & 2.86 \\
\hline
\end{tabular}

†Land use: 1-Wheat, 2-Clover, 3-Pasture

*significant at 0.05 level.

The soil nutrient contents of cultivated wheat and clover fields were generally lower than the uncultivated pasture. The change in magnesium content was significant $(\mathrm{P}<0.01)$ and the mean EC significantly decreased $(\mathrm{P}<0.05)$ in cultivated land. The EC values were 219, 256 and $303 \mu \mathrm{S} \mathrm{cm}{ }^{-1}$ in wheat fields, clover fields and pasture, respectively (Figure 6).

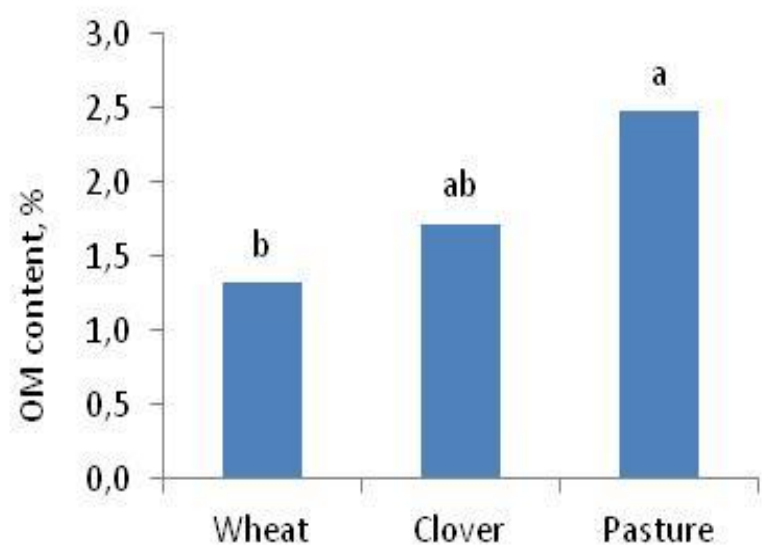

Figure 5. Effect of land use on organic matter content $(\mathrm{P}<0.05)$

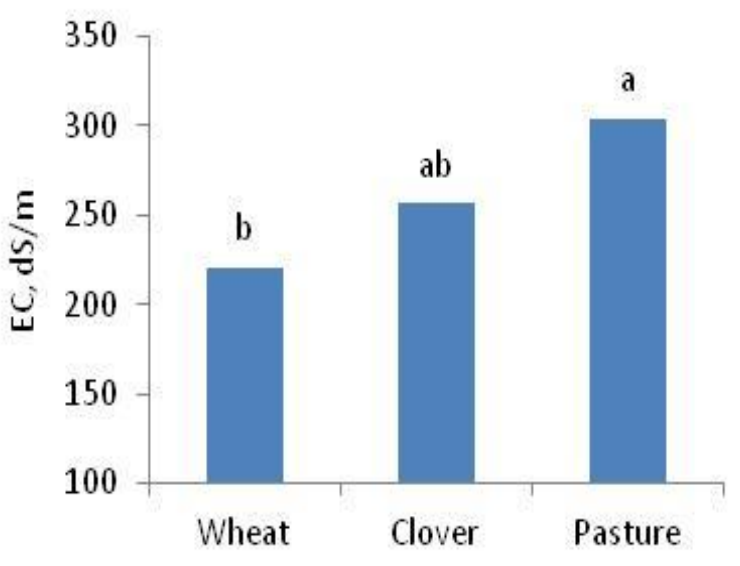

Figure 6. Effect of land use on EC $(\mathrm{P}<0.10)$. 


\section{Discussion}

Previous researchs have also shown that the soil physical properties, such as clay content and $\mathrm{pH}$, were strongly correlated with landscape position (Ovalles and Collins, 1986; Gregorich and Andersen, 1985). Similarly, Wang et al. (2001) reported that there were no significant differences in soil nutrients between different landscape positions. Smilarly Malo et al. (1974) also reported that clay content increased from the backslope to the footslope.

Aandahl (1948) reported that the topography affect runoff, drainage, soil temperature and soil erosion and consequently influence soil formation. In the current study, the clay, boron content and EC values increased from the backslope to the terrace positions, which is likely to be in response to surface runoff and leaching processes.

The results reveal that cultivation decreases soil nutrient levels, which has been reported by many researchers (Lepsch et al., 1994; Zheng et al., 1996). Gülser (2004) reported that the different cropping treatments increased soil organic matter, total $\mathrm{N}$, EC and exchangeable K contents in different levels when compared with the bare soil. Wang et al. (2001) found higher soil organic matter contents in uncultivated land than in cultivated land. Fu et al. (1999) and Hontoria et al. (1999) reported that land use and soil management practices influence the soil processes related to soil nutrients, such as erosion, oxidation, mineralization and leaching, and consequently modify the processes of transport and redistribution of nutrients. In this study, EC values, organic matter and magnesium contents also varied between different land uses.

\section{Conclusion}

This study provides the current status of soil environment in term of topographic position and land use types in the basin. Topography and land use had significant effects on clay, $\mathrm{pH}, \mathrm{EC}$, soil organic matter and nutrient contents in the Van Lake Basin, Turkey. The results of this study may help to better understanding of the effects of environmental components of soils on sustainable crop production and soil management.

\section{Acknowledgement}

Authors thanks to Yüzüncü Yıl University for laboroatory support of this research. Authors also thanks to Dr. Alex Boon in Edanz Group for his helps in English editing of the manuscript.

\section{References}

Aandahl, A.R.. 1948. The characterization of slope positions and their influence on the total nitrogen content of a few Virgin soils of Western Iowa. Soil Science Society of America Journal 13: 449-454.

Barreto, R., Tsegaye, T., Coleman, T.L., Shaffer, D., Tadesse, W., 2000. Land use effect on the distribution of soil physical and chemical properties under tropical rainforests of Puerto Rico. Geoscience and Remote Sensing Symposium Taking the Pulse of the Planet: The Role of Remote Sensing in Managing the Environment. 24-28 July 2000, Honolulu Hawaii, USA.

Bhatti, A.U., Mulla, D.J., Frasier, B.E.. 1991. Estimation of soil properties and wheat yields on complex eroded hills using geostatistics and thematic mapper images. Remote Sensing of Environment 37(3): 181-191.

Birkeland, P.W., 1999. Soils and Geomorphology. $3^{\text {rd }}$ Edition. Oxford University Press. New York, USA. 430p.

Black, C.A., 1965. Methods of Soil Analysis. Part 1. Physical and Mineralogical Properties, Including Statistics of Measurement and Sampling, Agronomy Monograph 9.1, American Society of Agronomy (ASA), Soil Science Society of America (SSSA), Madison, Wisconsin, USA.

Brubaker, S.C., Jones, A.J., Lewis, D.T., Frank, K., 1993. Soil properties associated with landscape positions. Soil Science Society of America Journal 57(1): 235-239.

Fu,B., Ma, K., Zhou, H., Chen, L., 1999. The effect of land use structure on the distribution of soil nutrients in the hilly area of the loess plateau, China. Chinese Science Bulletin 44(8): 732-736.

Gregorich, E.G., Anderson, D.W., 1985. Effects of cultivation and erosion on soils of four toposequences in the Canadian prairies. Geoderma 36(3-4): 343-354.

Garten, Jr. C.T., Ashwood, T.L., 2002. Landscape level differences in soil carbon and nitrogen: implications for soil carbon sequestration. Global Biogeochemical Cycles 16(4): 61-1-61-14.

Gülser, C., 2004. A comparison of some physical and chemical soil quality indicators influenced by different crop species. Pakistan Journal of Biological Sciences 7(6): 905-911.

Hontoria, C., Saa, A., Rodríguez-Murillo, J.C., 1999. Relationships between soil organic carbon and site characteristics in Peninsular Spain. Soil Science Society of America Journal 63(3): 614-621. 
Kacar, B., 1994. Bitki ve Toprağın Kimyasal Analizleri III. Toprak Analizleri. Ankara Üniversitesi Ziraat Fakültesi Eğitim Araştırma Ve Geliştirme Vakfı Yayınları No: 3, Ankara, Turkey. [in Turkish]

Lepsch, I.F., Menk, J.R.F., Oliveira, J.B., 1994. Carbon storage and other properties of soils under agriculture and natural vegetation in Sao Paulo State, Brazil. Soil Use and Management 10(1): 34-42.

Malo, D.D., Worcester, B.K., Cassel, D.K., Matzdorf, K.D., 1974. Soil-landscape relationships in a closed drainage system. Soil Science Society of America Journal 38(5): 813-818.

Miller, P.M., Singer, M.J., Nielsen, D.R., 1988. Spatial variability of wheat yield and soil properties on complex hills. Soil Science Society of America Journal 52(4): 1133-1141.

Ovalles, F.A., Collins, M.E., 1986. Soil-landscape relationships and soil variability in north central Florida. Soil Science Society of America Journal 50(2): 401-408.

Steel, R.G.D., Tore, J.H., 1996. Principle and Procedures of Statistics. : A Biometrical Approach. 3rd Revised edition, Mc Graw-Hill Company, New York, USA. 666p.

Wang, J., Fu, B., Qiu, Y., Chen, L., 2001. Soil nutrients in relation to land use and landscape position in the semi-arid small catchment on the loess plateau in China. Journal of Arid Environment 48(4): 537-550.

Yoo, K., Amundson, R., Heimsath, A.M., Dietrich, W.E.. 2006. Spatial patterns of soil organic carbon on hillslopes: Integrating geomorphic processes and the biological C cycle. Geoderma 130(1-2): 47-65.

Young, F.J., Hammer, R.D., 2000. Soil-landform relationships on a loess-mantled upland landscape in Missouri. Soil Science Society of America Journal 64(4): 1443-1454.

Zheng, D., Hunt, Jr., E.R., Running, S.W., 1996. Comparison of available soil water capacity estimated from topography and soil series information. Landscape Ecology 11(1): 3-14. 